\title{
Primary and Secondary School Students Perspective on Kolb-based STEM Module and Robotic Prototype
}

\author{
Noor Faridatul Ainun Zainal ${ }^{\# 1}$, Rosseni Din ${ }^{* 2}$, Nazatul Aini Abd Majid ${ }^{\# 3}$, \\ Mohammad Faidzul Nasrudin ${ }^{\# 4}$, Abdul Hadi Abd Rahman ${ }^{\# 5}$ \\ ${ }^{\#}$ Faculty of Information Science \& Technology, Universiti Kebangsaan Malaysia 43600 Bangi Malaysia

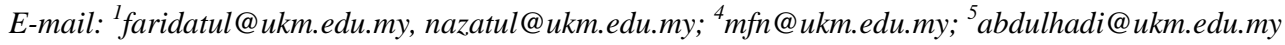 \\ *Faculty Faculty of Education, Universiti Kebangsaan Malaysia 43600 Bangi Malaysia \\ Email : ${ }^{2}$ rosseni@ukm.edu.my
}

\begin{abstract}
The aim of this paper is to assess students' perceptions of their competency and interests in Science, Technology, Engineering and Mathematics (STEM) throughout Malaysia. These perceptions are obtained during and after they were engaged in using a STEM module and building a robotic prototype that was in line with the STEM teachers' specification, and was conducted at the National Science Centre, Malaysia. This activity was undertaken because the target ratio for the number of students enrolling in STEM programs is not met. The developed STEM module is based on four stages of the learning cycle in Kolb's experiential learning theory. The stages are Concrete Experience, Reflective Observation, Abstract Conceptualization, and Active Experimentation. These stages have five key educational activities which are watching videos, reading modules, assembling robotic components, drag and drop using blockly software and lastly playing a robotic game. The key element of the activities is the utilization of a robotic prototype as the main component in increasing the students' interest in STEM via games. This module was evaluated in both qualitative and quantitative case studies of students to inform teachers' perceptions of the developed modules and robotic prototypes. Data were collected through two training events at a science exhibition at the National Science Centre and taken from two distinct groups, namely primary and secondary school students in range 11 to 15 year old. The evaluation comprised of five areas, which were interaction, engagement, challenge, competency, and interest. The results show that developed module and robotic prototype based $n$ teacher's perception received positive response from the respondents. It can efficiently raise students' interest in STEM that meets the Malaysia Education Blueprint 2013-2025.
\end{abstract}

Keywords - robotic module; STEM education; game-based learning; student perception; interest.

\section{INTRODUCTION}

The world is moving towards the fourth industrial revolution where it has embraced Artificial Intelligence (AI) technology, Malaysia is no exception. In order to take advantage of these changes, it is important to produce knowledgeable and competent human capital with adequate capabilities and creativity to lead this nation [1]. Consequently, countries are looking for strategies to develop young people's knowledge and skills to design and develop innovation, technology, and scientific literacy to verify their place in the global economy.

For many governments around the world, it is now a priority to increase the number of Science, Technology, Engineering, and Mathematics (STEM) graduates. This is not only important for the United States [2] and the UK [3], but also for Malaysia in order to achieve developed nation status By 2050. Malaysians need to be the creators of technology and not just technology users. Consequently, being an IT developer and creator country will require its people to have the skills within those STEM disciplines. This raises concerns, as more STEM-related industries will be developed in this country.

Current developments in Malaysia have also generated a very high interest in the integrated STEM approach in education. STEM is an interdisciplinary field that bridges the four disciplines of science, technology, engineering, and mathematics [4][5] and applies a real-world context by connecting the educational community with industry institutions to produce talented people who are STEM literate.

Australia, China, Korea, and Taiwan have strived to develop the STEM K-12 curriculum which is designed as an "integral cross-disciplinary approach in each STEM subject" [6]. Malaysia is in a slight dilemma and needs to increase 
promotion of the STEM education methodology because the number of students enrolling for science and non-science subjects has not reached the desired 60:40 ratio [7]. It is important to attract young students on STEM content to ensure they are motivated and on track to complete the required coursework in preparation to enroll on STEM degree courses [8]. [9] concludes that the motivation to pursue a STEM degree is influenced by the mathematical performance of students in the 12th grade. When students are exposed to mathematics and science courses at this time, it increases their self-efficacy. In order to raise the interest of Malaysian students in STEM subjects; various groups need to play their roles in organizing programs to promote STEM such as STEM Team Fair [10], Smart Click Camping [7], and continue to develop mobile apps for science textbooks such as iSains [11] and E-Star [12].

For effective STEM teaching, the methods used by the instructor must be up to date with technological change and the students' generation. For example, in Korea [13], various training programs for teachers have been suggested to help teachers deliver more effective content and instructional design to help improve students' thinking ability. In addition, appropriate teaching method should be adopted as the process of solving the problems in conventional practices are unstructured and unclear [14]. These conventional methods are more focused on the knowledge delivery processes which increase student dependence on the instructor. This process prevents students from learning and in-depth thinking. Thus, appropriate teaching methods need to be adopted. Many researchers have recognized the weaknesses in teaching and learning methods in Malaysia [4].

To ensure STEM education can appeal to students, the passive teaching method in the classroom needs to be changed to active learning that emphasizes creative thinking and enhanced skills like HOTS. HOTS is Higher Order Thinking Skill which was introduced to primary and secondary schools a few years ago. HOTS is a methodology to help fine tune the students ability to assess, apply, analyze and create [15]. These advanced skills will allow the student to explain, make decisions, troubleshoot problems and innovate quicker and more accurately. Introducing robotic kits into the primary and secondary education, for example, is one of the most effective ways to engage the young mind in STEM disciplines and give them early hands-on experience [16]. As well as motivating students to participate in STEM subjects in a positive vain [17][18][19], Robotics has also proven to be an effective tool to engage and stimulate teachers' interest in STEM learning and teaching [20]. Robotic activities integrate STEM and develop the skills necessary for a modern skilled workforce including creativity [21][22], cooperation [23][24], critical thinking [25], computational thinking [26][27], and communication skills [28]. The main question is how to design a STEM module that uses robotics to improve the learner's cognitive processes.

Kolb [29] has developed a learning theory that uses robotics to improve the learners' cognitive processes and is based on experience. Kolb's experiential learning style theory has four stages namely a) Concrete experiential b) Reflective Observation c) Abstract Conceptualization and d)
Active Experimentation. Successful learning outcomes will be achieved when the student has completed the four stages. The Objective of this paper is to evaluate a STEM module based on Kolb's learning model by utilizing a low-cost robot prototype.

The Kolb learning model was chosen for this study because the theory is concerned with the learner's internal cognitive processes. S. M. Salleh, Z. Shukur, and H. M. Judi, [30] have made comparisons in the study of implementation strategies in programming learning using cognitive load theory (CLT). Robots are also one of the strategies or tools used [31] to reduce cognitive load. The robot is not only used for high school students but also for university students. Robotics has become part of the university curriculum because robots have proven to aid effective learning [32] Kolbs states that learning involves the acquisition of abstract concepts that can be applied flexibly in various situations. In Kolbs' theory, the impetus for the development of new concepts is derived from new experiences [29]. The STEM module based on Kolb's theory [33] has been analyzed after a STEM survey of Malaysia teachers to find ways how to increase students' interest in STEM education. [33] introduced the first version of the module that was developed. It incorporates an affordable, low-cost robotic kit integrated with robotic programming modules, which can be built and owned by the students. Unfortunately, primary and secondary students have not yet evaluated the module. Consequently, this paper will explain in detail all aspects and features in the new version of the module with a better guidebook and videos. The outcomes from evaluating the module with the study respondents will also be discussed.

\section{MATERIAL AND METHOD}

This study was conducted to determine the effectiveness of using the module and the robotic prototype developed based on STEM teacher specification ${ }^{1}$. The effectiveness of this module is measured by looking at the increased interest and competency of school students towards STEM after carrying out the module activities. The module in this study consists of a video (Figure 1), a guidebook module (Figure 2), blockly software (Figure 3) and the robotic prototype (Figure4). Blockly software is a web-based visual program that allows an easier and interactive approach to writing program code using the drag and drop technique. The blockly software can also improve beginner performance on some programming activities, specifically through increased time on task and quicker, more frequent achievement of programming goals [34].

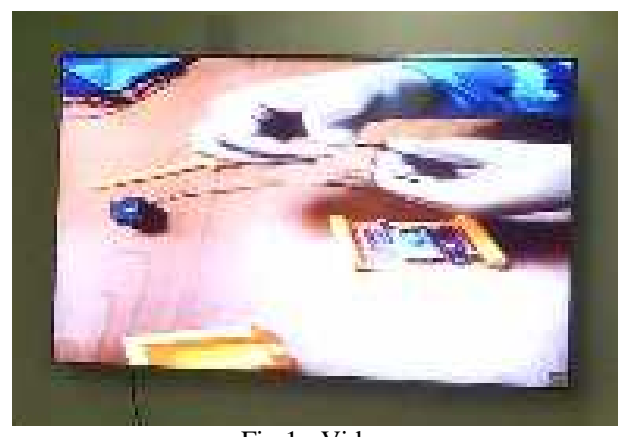

Fig 1: Video 


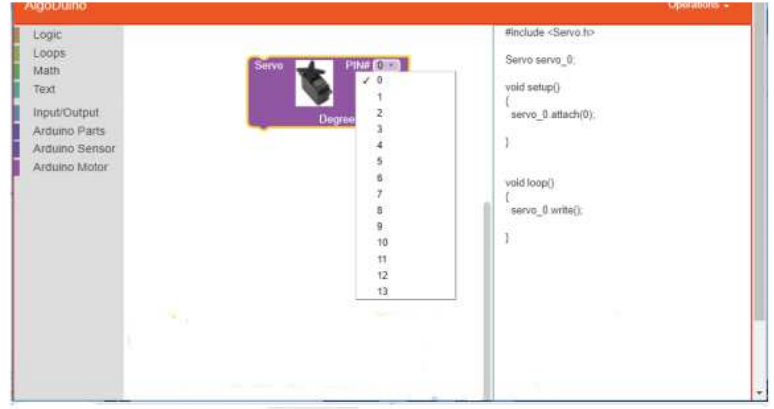

Fig 2: Guide Book Module

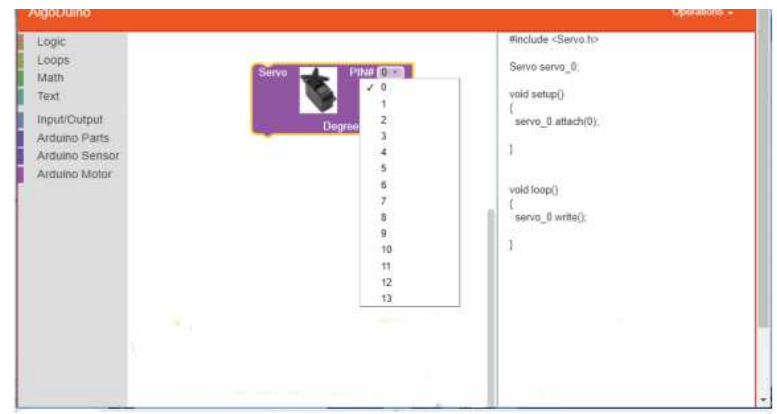

Fig 3: Blockly Software

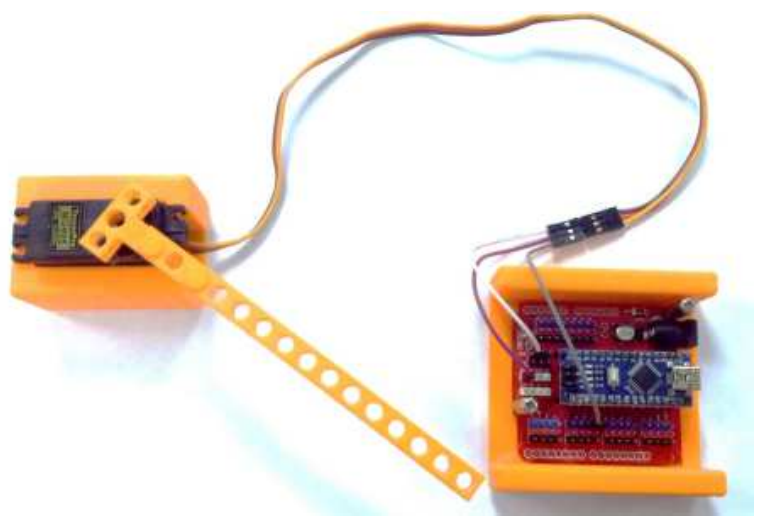

Fig 4: Robotic Prototype

The proposed STEM module is based on four stages of the learning cycle in Kolb's experiential learning theory. The stages are Concrete Experience, Reflection Observation, Abstract Conceptualization, and Active Experimentation. These stages have five key educational activities, which are: (1) watching videos, (2) reading modules, (3) assembling robotic components, (4) drag and drop using blockly software and lastly (5) playing a robotic game. This module aims to incorporate angles (degree), robot, visual programming, and a game. The integration of the key activities with the Kolb's learning stages is shown in Figure 5. A brief explanation of each stage is given below:

1) The first stage is concrete Experience, was a new experience of the situation is encountered. Videos are shown to participants to help them understand the main idea of the activity and the math concepts. The STEM module uses video in this way to make sure that the learning process is in line with current technological changes.

2) Reflective observation is after the acquirement of a new experience where occurring experience and understanding relationships. Once participants learn and have a new experience from the video, they gain a deeper understanding from experience and further enhance this through the concepts outlined in the Guide Book module. To test their understanding, participants use their newly acquired knowledge to do exercises about angles; they can also observe how the math concept is used to determine the direction via the guidebook module. This module is developed by using info graphic features to reduce the burden of cognitive learning.

3) Abstract Conceptualization is where the student reflects on the new ideas and raises them to abstract concepts. Participants need to think how to turn the new knowledge into logic by arranging visual blocks in blockly software. Both of these activities offer new experiences by participants watching the video at the beginning of the cycle.

4) Active Experimentation is where participants apply the new knowledge and experiences gained at the beginning of the learning circle. Once the robot has been fully developed, participants will perform some experiments and play with logic by changing the angles and degrees in the code sequence so they can win in this game.

The most effective learning outcome is when a student goes through all the four cycles of Kolb's model. Figure 5 shows the activities and events based on the learning model.

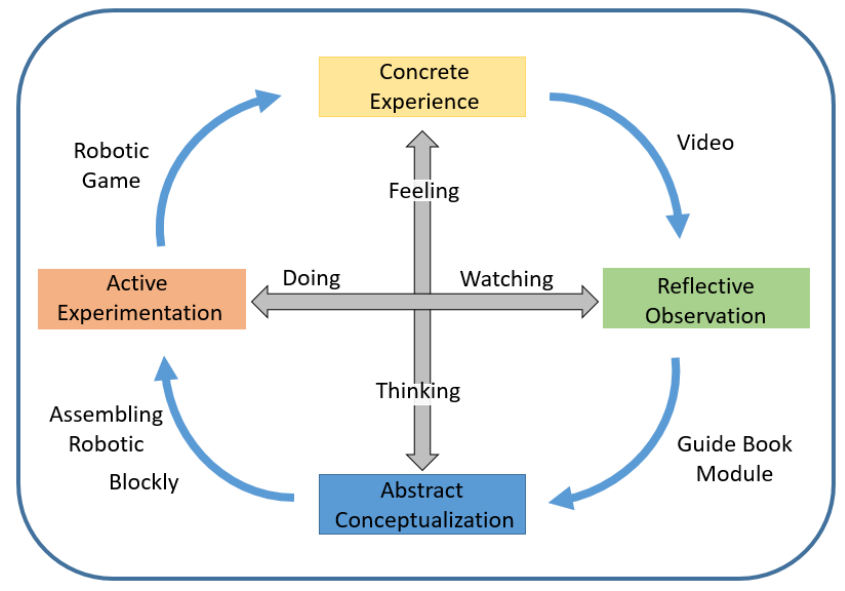

Fig 5: STEM discovery Programming Robotic - based Kolb's learning model

The evaluation was conducted with primary and secondary participants attending a science exhibition at the National Science Centre. 67 questionnaires were distributed in two workshop sessions for primary school $(\mathrm{N}=39)$ and secondary school $(\mathrm{N}=28)$. The questionnaire was based on the instrument presented by [35] using a five-point Likert scale, ranging from "Strongly Disagree" (1) to "Strongly Agree" (5). For the use of the instrument or questionnaire in this study, the researcher sought permission to use, modify, and translate the items according to the objective research. After the workshop, the students were given questionnaires that consisted of 23 questions; 19 close-ended and four open-ended. The questionnaire was classified into five domain categories i) Interaction ii) Engagement iii) 
Challenge iv) Competency and v) Interest [35]. Apart from the questionnaire, observations and interviews were also conducted to obtain more feedback that is detailed. An expert for the entire 19 items as shown in Table I tested the validity of this questionnaire.

TABLE I

NUMBER OF ITEMS BY DOMAIN

\begin{tabular}{|c|c|}
\hline Domain & Number of Items \\
\hline Interaction & 4 \\
\hline Engagement & 3 \\
\hline Challenge & 4 \\
\hline Competency & 6 \\
\hline Interest & 2 \\
\hline
\end{tabular}

\section{RESULT AND DISCUSSION}

This section will present two parts: student demographics analysis and student perceptions of the activities that they were involved.

\section{A. Student Demography Analysis}

The study consisted of 67 respondents, of which, 39 were primary school students and 28 secondary school students, their ages ranging from 11 and 15 years old. All the primary school students were 12-year-olds with 23 females and 15 males participating. The secondary school students comprised of all male students with 6 of them aged 14 and the remaining 22 aged 15 . This is in line with the study objective, which is to increase the students' interest in STEM before they actually enroll for secondary school (Form 4). Figure 6 shows the number of students in the school category and the breakdown of gender.

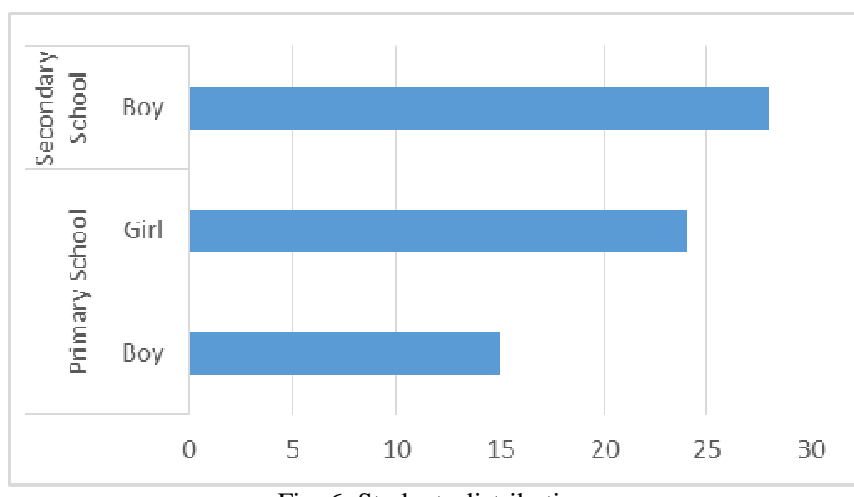

Fig. 6: Students distribution

\section{B. Students' Perception}

The result for the student perception is shown in Table II.
TABLE II

THE ITEMS IN QUESTIONNAIRE

\begin{tabular}{|c|c|c|c|c|}
\hline Num. & Item & Mean & $\begin{array}{c}\text { Std. } \\
\text { Deviation }\end{array}$ & $\mathbf{N}$ \\
\hline $\mathrm{q} 1$ & $\begin{array}{l}\text { The activity was } \\
\text { enjoyable }\end{array}$ & 4.78 & 0.419 & 67 \\
\hline$q 2$ & $\begin{array}{l}\text { The activity was } \\
\text { interesting }\end{array}$ & 4.71 & 0.455 & 67 \\
\hline q3 & $\begin{array}{l}\text { I was engaged in the } \\
\text { activity }\end{array}$ & 4.46 & 0.668 & 67 \\
\hline $\mathrm{q} 4$ & $\begin{array}{l}\text { Asking question to } \\
\text { other students }\end{array}$ & 3.33 & 1.437 & 67 \\
\hline$q 5$ & $\begin{array}{l}\text { Observing other } \\
\text { students }\end{array}$ & 4.05 & 1.224 & 67 \\
\hline q6 & $\begin{array}{l}\text { Discussions with other } \\
\text { students }\end{array}$ & 4.30 & 1.131 & 67 \\
\hline q7 & $\begin{array}{l}\text { Interacting with other } \\
\text { students }\end{array}$ & 4.41 & 0.978 & 67 \\
\hline q8 & $\begin{array}{l}\text { I felt that I learned } \\
\text { important skills }\end{array}$ & 4.44 & 0.736 & 67 \\
\hline q9 & $\begin{array}{l}\text { I felt a sense of } \\
\text { accomplishment after } \\
\text { completing the activity }\end{array}$ & 4.44 & 0.799 & 67 \\
\hline q10 & $\begin{array}{l}\text { The activity improved } \\
\text { my competency and } \\
\text { interest in Sciences } \\
\text { subject }\end{array}$ & 4.30 & 0.775 & 67 \\
\hline q11 & $\begin{array}{l}\text { The activity improved } \\
\text { my competency and } \\
\text { interest in Technology } \\
\text { subject }\end{array}$ & 4.32 & 0.839 & 67 \\
\hline$q 12$ & $\begin{array}{l}\text { The activity improved } \\
\text { my competency and } \\
\text { interest in Engineering } \\
\text { subject }\end{array}$ & 4.05 & 0.958 & 67 \\
\hline q13 & $\begin{array}{l}\text { The activity improved } \\
\text { my competency and } \\
\text { interest in } \\
\text { Mathematics subject }\end{array}$ & 3.98 & 1.198 & 67 \\
\hline q14 & $\begin{array}{l}\text { The activity Assemble } \\
\text { robot were difficult }\end{array}$ & 2.54 & 1.595 & 67 \\
\hline q15 & $\begin{array}{l}\text { The activity use } \\
\text { blockly software were } \\
\text { difficult }\end{array}$ & 2.32 & 1.446 & 67 \\
\hline q16 & $\begin{array}{l}\text { The activity use angle } \\
\text { were difficult }\end{array}$ & 2.70 & 1.509 & 67 \\
\hline q17 & $\begin{array}{l}\text { The activity was } \\
\text { challenging }\end{array}$ & 3.22 & 1.442 & 67 \\
\hline q18 & $\begin{array}{l}\text { The activity increased } \\
\text { my curiosity and } \\
\text { interest in this area }\end{array}$ & 4.67 & 0.475 & 67 \\
\hline q19 & $\begin{array}{l}\text { The activity } \\
\text { encouraged me to } \\
\text { learn more about this } \\
\text { topic }\end{array}$ & 4.52 & 0.737 & 67 \\
\hline
\end{tabular}


TABLE III

NUMBER OF ITEMS BY DOMAIN

\begin{tabular}{|c|c|}
\hline Domain & Item Number \\
\hline Engagement & $\mathrm{q} 1, \mathrm{q} 2, \mathrm{q} 3$ \\
\hline Interaction & $\mathrm{q} 4, \mathrm{q} 5, \mathrm{q} 6, \mathrm{q} 7$ \\
\hline Competency & $\mathrm{q} 8, \mathrm{q} 9, \mathrm{q} 10, \mathrm{q} 11, \mathrm{q} 12, \mathrm{q} 13$ \\
\hline Challenge & $\mathrm{q} 14, \mathrm{q} 15, \mathrm{q} 16, \mathrm{q} 17$ \\
\hline Interest & $\mathrm{q} 18, \mathrm{q} 19$ \\
\hline
\end{tabular}

Table III shows five categories of questions that have been answered by primary and secondary students. The Likert scale was used in the questionnaire. Three mean scale categories were created which are low $(1-2.33)$, moderate (2.34 - 3.66), and high (3.67 - 5) [36][37]. Overall Table IV shows that students enjoy the activities because items $1,2,3$ and 4 show high mean values for primary and secondary schools. However, the mean value of the challenge is moderate which is not too difficult and not too easy for both sets of students.

TABLE IV

STUdENTS' PRIMARY SCHOOL FEEDBACK

\begin{tabular}{|l|c|c|c|c|}
\hline \multicolumn{1}{|c|}{ Item } & $\begin{array}{c}\text { Primary } \\
\text { School } \\
\text { (Mean) }\end{array}$ & Level & $\begin{array}{c}\text { Std. } \\
\text { Deviation }\end{array}$ & N \\
\hline Engagement & 4.60 & High & 0.588 & 39 \\
\hline Interaction & 4.11 & High & 1.242 & 39 \\
\hline Competency & 4.29 & High & 1.003 & 39 \\
\hline Interest & 4.62 & High & 0.629 & 39 \\
\hline Challenge & 3.04 & Moderate & 1.559 & 39 \\
\hline
\end{tabular}

TABLE V

STUDENTS' SECONDARY SCHOOL FEEDBACK

\begin{tabular}{|l|c|c|c|c|}
\hline \multicolumn{1}{|c|}{ Item } & $\begin{array}{c}\text { Secondary } \\
\text { School } \\
\text { (Mean) }\end{array}$ & Level & $\begin{array}{c}\text { Std. } \\
\text { Division }\end{array}$ & N \\
\hline Engagement & 4.75 & High & 0.436 & 28 \\
\hline Interaction & 3.99 & High & 1.270 & 28 \\
\hline Competency & 4.28 & High & 0.750 & 28 \\
\hline Interest & 4.63 & High & 0.590 & 28 \\
\hline Challenge & 2.39 & Moderate & 1.470 & 28 \\
\hline
\end{tabular}

\section{1) Engagement}

Engagement is the level in which people are interested in the work of an organization, be it educational or corporate. In the study, engagement looks at the willingness of students to participate in the activity. Table 5 and Table 6 show that students have high engagement, and from the researcher's observation, students are keen to participate as they have tried to engage right from the start.

\section{2) Interaction}

Interaction is where two or more students communicate or react to each other. This occurs when students' perform the activity, which is designed, so the students have to find a partner in order to solve the activity. All the processes in this study apply collaborative learning, so the process of learning and cooperation happens together. There are 3 or 4 students in a group, and Table IV and Table $\mathrm{V}$ show a high number collaborating to solve problems and complete the tasks to win the competition.

\section{3) Students' competence}

Competency is an essential skill required to do a job. In this study, it measures the student learning and activity outcomes. Students also noted that at the end of this activity, their competence in STEM courses had also increased. Table IV and Table V show that their competency is increased in STEM courses for both student categories. Table IV also shows high competency for all module and prototype courses.

TABLE VI

High COMPETENCY PERCEPTION FOR BOTH CATEgORIES STUdENT FOR EACH COURSE

\begin{tabular}{|c|c|c|}
\hline Course & $\begin{array}{c}\text { Primary } \\
\text { School }\end{array}$ & $\begin{array}{c}\text { Secondary } \\
\text { School }\end{array}$ \\
\hline Science & 4.39 & 4.06 \\
\hline Technology & 4.39 & 4.11 \\
\hline Engineering & 4.07 & 3.97 \\
\hline Mathematics & 3.97 & 4.02 \\
\hline
\end{tabular}

\section{4) Students' Interest}

Interest is a feeling of wanting to give attention to something or to be involved and learn more about something. In this study, it is observed whether the activities conducted are enjoyed by the students and are the correct subjects that students like to spend time learning about. Tables IV and Table V show high levels of interest and curiosity. The interest stage is similar to the competency one, which measures learning outcomes after doing activities.

\section{5) Challenge}

Challenge test one's capabilities and determination and requires extra mental or physical effort to be successful. Consequently, this study measures the difficulty of students who complete the task. Table 5 and Table 6 show that the challenge is a moderate one for students in both educational categories. Primary school students state that the assembling of robots (3.24) and the use of blockly software (2.72) is moderately difficult. The results show that High school students also found both activities moderately challenging (2.14) (2.27). Scale values show that secondary school students are more attracted to the use of blockly software while primary school students are more interested in robotic assembling.

The results shown in Table 5 and Table 6 are supported by the students' answers given in the questionnaire. Most students stated that assembling robotics is not difficult. 
"Not difficult...to build a robot is easy" (Age 11, female)

"It is easy because it is already equipped with components and manuals" (Age 12, female)

"Not difficult because it is fun" (Age 12, male)

"Not difficult because I am interested in this technology" (Age 14, male)

"Not difficult because able to see the procedure well" (Age 15, male)

"Not difficult. If we follow the instructions provided, then it is easy to understand it" (Age 15, male)

Students also show a positive response in using blockly software for writing program code.

"The use of this mBlock is not too difficult because it is fun" (Age 12, female)

"Not difficult because it is easy to control" (Age 12, male)

"Not difficult because it is easy to understand" (Age 12, female)

"It is not difficult after watched videos" (Age 15, male)

"Has a simple manual" (Age 14, male)

"Not difficult because I am interested" (Age 14, male)

Overall, the students stated that this activity was interesting and they were interested in doing something more challenging.

"I hope to make a more robust robot, and my suggestion is to reduce editing in blockly software" (Age 15, male)

"My hope for the next robotic module is more challenging and interesting" (Age 15, female)

"I hope there are flying robots" (Age 12, male)

"Build a robot ship" (Age 14, male)

"Build a jumping frog" (Age 15, male)

Figure 7 below shows students doing the five key activities. Figure 7 (a) shows that participants are watching the video and understand the maths concept and getting an overview of the activities they will do later.

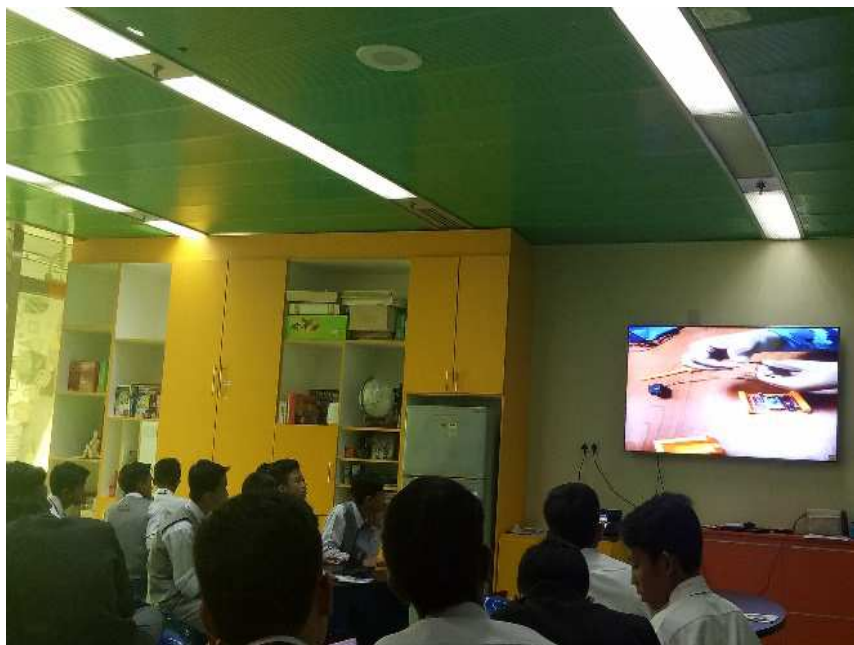

Fig. 7 (a) Watching the video

Figure 7 (b) shows participants in understanding the knowledge they have acquired using the module.

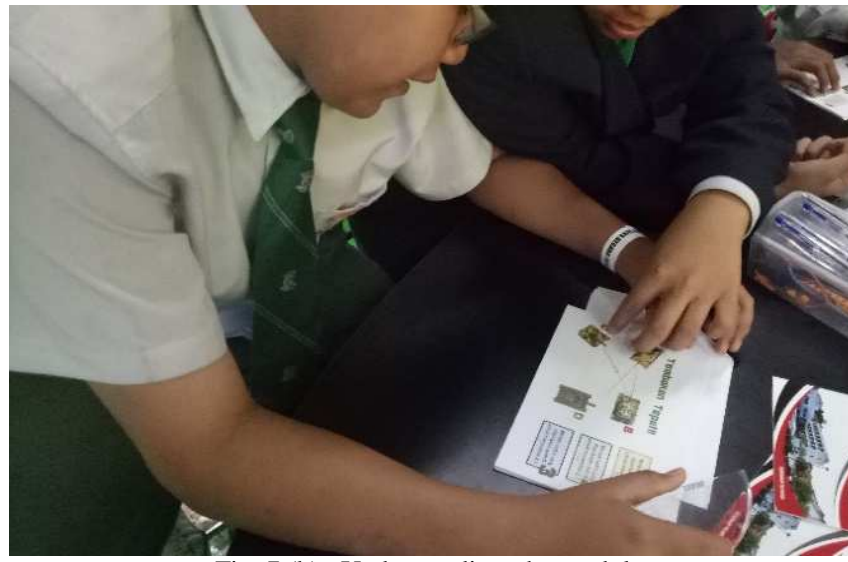

Fig. 7 (b) Understanding the module

Figures 7 (c) and 7 (d) illustrate the participants who were trying to convert knowledge into logic by assembling the robotic components and by arranging the blockly to generate the robotic function.

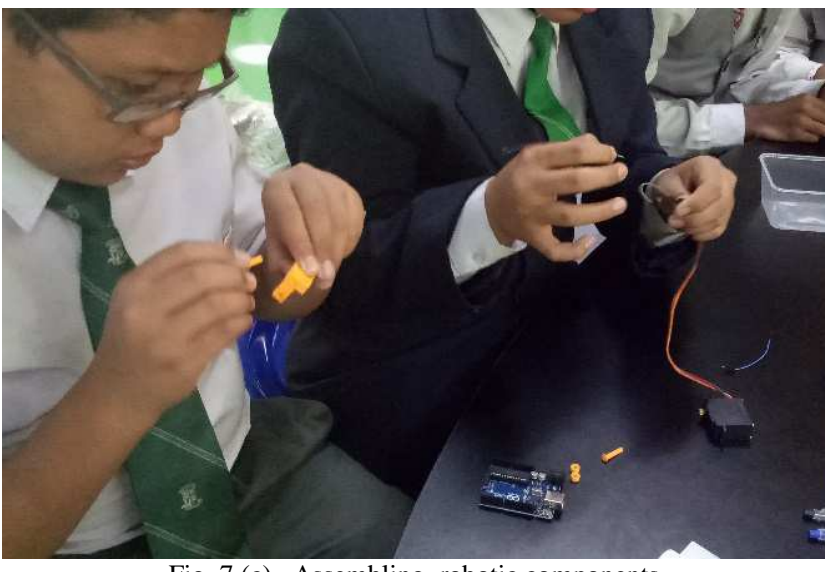

Fig. 7 (c) Assembling robotic components 


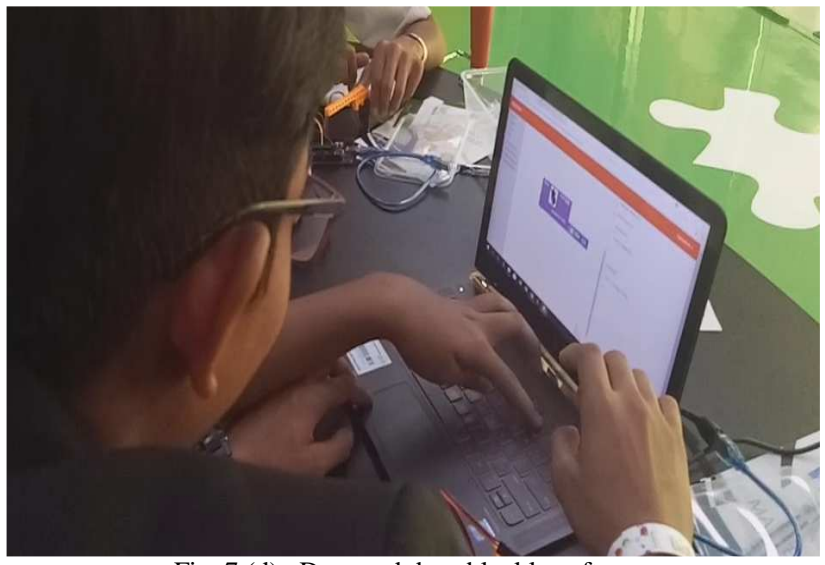

Fig. 7 (d) Drag and drop blockly software

Figure 7 (e) shows participants doing the active experiment by changing the logic and rearrange the Blockly to win the game using a low-cost robot.

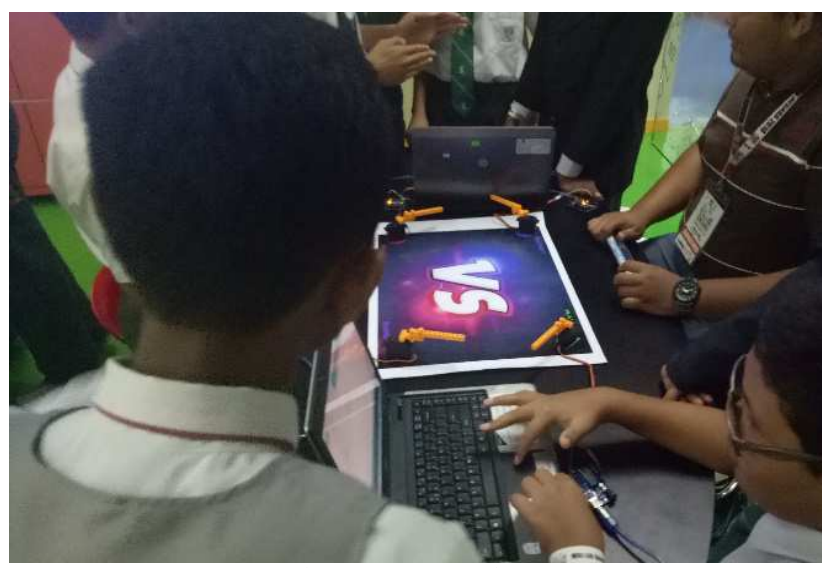

Fig. 7 (e) Game time

Based on the research findings by [33], the specified module specifications are Hands-on and a Conceptual game. From Table IV it is observed that by the constructing interaction the students give a high commitment to the project. The Competence and Interest elements which are also the construct gives added value to the learning outcomes, and it also shows high value as mentioned in Table IV and Table V. This means that the activities carried out to enhance the student's competency and interest in the STEM. However, the value for the construct challenge provides a moderate value. The moderate value does not mean they are not interested in this activity although the value given by the students to. The statements given by the students show they need challenges. This shows that this activity has attracted them and they want something more. According to [38], students who are interested in a subject, will be more involved in their assignment, put more effort into their studies and engage in a deeper level of thinking. The researcher believes that the increased involvement of students in mathematics and science in schools will ultimately lead to more of them pursuing mathematics and science-related after-school activities, and give them aspirations of science and science careers.

\section{CONCLUSION}

A STEM module that integrated angles (math), Blockly (virtual programming), and game based on Kolb's learning model were evaluated and discussed. The problem in increasing students' interests can be tackled by giving them hands-on activities, robot and games based on the developed module. However, high robotic prices cause universities and schools not to provide robots to every student. Therefore, with advanced STEM modules that meet the specifications and fulfill the needs of the students and teachers' expectations, robotic usage can help the learning of STEM and can attract students to choose the sciences. It is hoped that the 60:40 policy could be achieved and maintained shortly, and the Malaysian Education Blueprint 2013-2025 (Malaysia Education Blueprint, 2013) can be implemented as projected.

The outputs of the research are a robotic programming module specification and a robot prototype specification. The significant outcome of this research is that it can efficiently raise students' interest in the STEM that meets the Malaysia Education Blueprint 2013-2025. Also, with the low cost of robotic prototypes, students in the urban or rural area can obtain these robots and learn the latest data which leads to 4.0 education. Most rural students are always left behind in this technology, so this teaching method will help reduce the gap between country and city pupils. The cost of the module is affordable, not only for the school, but it also can be acceptable for the students too. We also considered to applying computational thinking in the next module, as it is a problem-solving process including some characteristics and dispositions. It is s also essential in the development of computer applications, but can also be used to support problem-solving across all disciplines.

\section{ACKNOWLEDGMENT}

The authors would like to thank the Universiti Kebangsaan Malaysia and the Ministry of Higher Education of Malaysia for their support in making this project possible. This research is supported by the FRGS/1/2017/ICT04/UKM/1 and supported by the Ministry of Higher Education of Malaysia.

\section{REFERENCES}

[1] H. M. Fadzil and R. M. Saat, "Enhancing STEM Education during School Transition: Bridging the Gap in Science Manipulative Skills," EURASIA J. Math. Sci. Technol. Educ., vol. 10, no. 3, pp. 209-218, Jun. 2014.

[2] E. Susilo et al., "STORMLab for STEM Education: An Affordable Modular Robotic Kit for Integrated Science, Technology, Engineering, and Math Education," IEEE Robot. Autom. Mag., vol. 23, no. 2, pp. 47-55, 2016.

[3] S. Ziaeefard, N. Mahmoudian, M. Miller, and M. Rastgaar, "Engaging students in STEM learning through co-robotic hands-on activities (Evaluation)," in ASEE Annual Conference and Exposition, Conference Proceedings, 2016, vol. 2016-June.

[4] C. C. Meng, N. Idris, and L. K. Eu, "Secondary Students' Perceptions of Assessments in Science, Technology, Engineering, and Mathematics (STEM)," EURASIA J. Math. Sci. Technol. Educ., vol. 10, no. 3, pp. 219-227, Jun. 2014.

[5] K. Francis-Poscente and B. Davis, "Lego Robotics Teacher Professional Learning," in First Meeting between the National Pedagogic University and the Faculty of Education of the University of Calgary, 2013, pp. 113-117. 
[6] J. Fan, S., \& Ritz, "International Views of STEM Education," in Proceedings PATT-28 Conference, 2014, pp. 4-14.

[7] Aina Nasa \& Zafira Anwar, "Too few STEM students," New Straits Time, 2016. [Online]. https://www.nst.com.my/news/2016/05/147260/too-few-stemstudents. [Accessed: 28-Nov-2017].

[8] N. K. DeJarnette, "America's children: Providing early exposure to STEM (science, technology, engineering and math) initiatives," Education, vol. 133, pp. 77-84, 2012.

[9] X. Wang, "Why Students Choose STEM Majors: Motivation, High School Learning, and Postsecondary Context of Support," Am. Educ. Res. J., vol. 50, no. 5, pp. 1081-1121, 2013.

[10] The Star, "PM: Success STEMs," 7 Jun 2014, 2014. [Online]. Available: https://www.thestar.com.my/news/nation/2014/06/07/pmsuccess-stems-from-motivation-dont-be-afraid-of-subjects-likescience-and-math/. [Accessed: 28-Nov-2017].

[11] N. A. Abd Majid and N. K. Husain, "Mobile learning application based on augmented reality for science subject: Isains," ARPN J. Eng. Appl. Sci., vol. 9, no. 9, pp. 1455-1460, 2014.

[12] V. Gopalan et al., "Evaluation of E-star: An enhanced science textbook using augmented reality among lower secondary school students," J. Teknol., vol. 77, no. 29, pp. 55-61, 2015.

[13] H. S. Park, A. Hiroyuki, and J. M. Kim, "The Extraction of Knowledge Factors of Teachers for Physical Computing Education," Int. J. Adv. Sci. Eng. Inf. Technol., vol. 8, no. 1, pp. 30-36, 2018.

[14] A. B. Bawamohiddin and R. Razali, "Problem-based learning for programming education,” Int. J. Adv. Sci. Eng. Inf. Technol., vol. 7, no. 6, pp. 2035-2050, Jan. 2017.

[15] Kementerian Pendidikan Malaysia, Kemahiran Berfikir Aras Tinggi Aplikasi di Sekolah. Kementerian Pendidikan Malaysia Bahagian Pembangunan Kurikulum, 2014.

[16] S. Bruder and K. Wedeward, "Robotics in the Classroom," IEEE Robotics and Automation Magazine, vol. 10, no. 3. pp. 25-29, 2003.

[17] P. Mosley, G. Ardito and L. Scollins, "Robotic Cooperative Learning Promotes Student STEM Interest," Am. J. Eng. Educ., vol. 7, no. 2, 2016

[18] S. Ludi, "Section 2 Educational Robotics in K-12 Formal Learning Chapter 5 Robotics and Problem-Based Learning in STEM Formal Educational Environments."

[19] A. J. L. J McLurkin, J Rykowski, M John, Q Kaseman, Using MultiRobot Systems for Engineering Education: Teaching and Outreach with Large Numbers of an Advanced, Low-Cost Robot, vol. 56, no. 1. Institute of Electrical and Electronics Engineers, 1963.

[20] C. Chalmers, B. Wightman, and R. Nason, "Engaging students (and their teachers) in STEM through robotics," Fac. Educ., Jul. 2014

[21] J. Ben Brahim, T., Marghitu, D. \& Weaver, "A Survey on Robotic Educational Platforms for K-12," in E-Learn: World Conference on E-Learning in Corporate, Government, Healthcare and Higher Education, 2012, vol. 2012, no. 1, pp. 41-48.

[22] T. a Mikropoulos and I. Bellou, "Educational Robotics as Mindtools," Themes Sci. Technol. Educ., 2013.
[23] G. Ardito, P. Mosley, and L. Scollins, "WE, ROBOT Using Robotics to Promote Collaborative and Mathematics Learning in a Middle School Classroom,” Middle Grades Res. J., 2014.

[24] A. Yuen, T.T., Boecking, M., Stone, J., Tiger, E.P., Gomez, A., Guillen, A. \& Arreguin, "Group Tasks, Activities, Dynamics, and Interactions in Collaborative Robotics Projects with Elementary and Middle School Children,” J. STEM Educ. Innov. Res., vol. 15, no. 1, pp. 39-45, 2014.

[25] S. Blanchard, V. Freiman, and N. Lirrete-Pitre, "Strategies used by elementary schoolchildren solving robotics-based complex tasks: innovative potential of technology," Procedia - Soc. Behav. Sci., vol. 2, no. 2, pp. 2851-2857, Jan. 2010.

[26] S. Atmatzidou and S. Demetriadis, "Advancing students' computational thinking skills through educational robotics: A study on age and gender relevant differences," Rob. Auton. Syst., vol. 75, pp. 661-670, Jan. 2016.

[27] T. Keane, C. Chalmers, M. Williams, and M. Boden, "The impact of humanoid robots on students' computational thinking," Sch. Teach. Educ. Leadership; Fac. Educ., 2016.

[28] Nelson Carl A., "Generating Transferable Skills in STEM through Educational Robotics," in Robots in K-12 Education, University of Nebraska-Lincoln, USA: IGI Global, 2012, pp. 54-65.

[29] D. A. Kolb, Experiential learning: experience as the source of learning and development. 1984

[30] S. M. Salleh, Z. Shukur, and H. M. Judi, "Scaffolding Model for Efficient Programming Learning Based on Cognitive Load Theory," Int. J. Pure Appl. Math., vol. 118, no. 7, pp. 77-83, 2018.

[31] R. Mason and G. Cooper, "Mindstorms robots and the application of cognitive load theory in introductory programming Publication details," Comput. Sci. Educ., vol. 23, no. 4, pp. 296-314, 2013.

[32] K. C. Yir, H. Arshad, and E. Sundararajan, "Offline Programming to Control Robot Manipulator in Virtual Kinematic Learning Tool," Adv. Mater. Res., vol. 845, pp. 740-744, Dec. 2013.

[33] N. F. A. Zainal et al., "Robotic prototype and module specification for increasing the interest of Malaysian students in STEM Education,” Int. J. Eng. Technol., vol. 7, no. 25, pp. 286-290, 2018.

[34] T. W. Price and T. Barnes, "Comparing Textual and Block Interfaces in a Novice Programming Environment."

[35] A. Konak, T. K. Clark, and M. Nasereddin, "Using Kolb's Experiential Learning Cycle to improve student learning in virtual computer laboratories," Comput. Educ., vol. 72, pp. 11-22, Mar. 2014.

[36] M. A. Zahiri Megat Zakaria, B. Aris, and J. Harun, "Kemahiran ICT di Kalangan Guru-Guru Pelatih UTM : Satu Tinjauan," 1st Int. Malaysian Educ. Technol. Conv., 2007.

[37] Jamil Ahmad and Subahan Meerah, "Pemupukan budaya penyelidikan di kalangan guru di sekolah: Satu penilaian.," Universiti Kebangsaan Malaysia, 2002.

[38] U.S. Department of Education, "National education technology plan 2010," National education technology plan 2010, 2010. [Online]. Available: http://www.ed.gov/technology/netp2010/recommendations [Accessed: 03-Jul-2018]. 